\title{
Surgical site infection: main cause of readmission of patients undergoing cardiac surgery
}

\author{
BRN Barreiros, EF Bianchi, RTN Turrini, RA Lacerda*, V De Brito Poveda \\ From 3rd International Conference on Prevention and Infection Control (ICPIC 2015) \\ Geneva, Switzerland. 16-19 June 2015
}

\section{Introduction}

Readmissions are a frequent problem in health institutions, bringing discomfort to the patient and family, and weigh the health system and society, therefore, cardiac patients suffer multiple readmissions to achieve full control of the disease or death, due to the complexity and the difficult management of cardiovascular diseases. Among the common causes of readmission there are the infections related to health care.

\section{Objectives}

To characterize the readmission cardiac patients after the surgical procedure.

\section{Methods}

This is a quantitative, retrospective, descriptive study, conducted through the medical records of patients who underwent cardiac surgery and subsequent readmission.

\section{Results}

The sample consisted of 62 patients readmitted after performing heart surgery, these $66 \%$ were male, with predominant age group of 61 to 70 years and the comorbidities that stood out was hypertension (80\%). The surgical site infection was the leading cause of rehospitalization, significantly associated to the variables obesity and dyslipidemia.

\section{Conclusion}

The identification of patients at risk for the development of surgical site infection can minimize readmission rates and reduce the costs associated with care, and must therefore, be subject to a different action planning by the nursing staff.

Medical-Surgical, Nursing School of University of São Paulo, São Paulo, Brazil

\section{Disclosure of interest}

None declared.

Published: 16 June 2015

doi:10.1186/2047-2994-4-S1-P74

Cite this article as: Barreiros et al: Surgical site infection: main cause of readmission of patients undergoing cardiac surgery. Antimicrobial

Resistance and Infection Control 2015 4(Suppl 1):P74.
Submit your next manuscript to BioMed Central and take full advantage of:

- Convenient online submission

- Thorough peer review

- No space constraints or color figure charges

- Immediate publication on acceptance

- Inclusion in PubMed, CAS, Scopus and Google Scholar

- Research which is freely available for redistribution
() Biomed Central

(c) 2015 Barreiros et al; licensee BioMed Central Ltd. This is an Open Access article distributed under the terms of the Creative Commons Attribution License (http://creativecommons.org/licenses/by/4.0), which permits unrestricted use, distribution, and reproduction in any medium, provided the original work is properly cited. The Creative Commons Public Domain Dedication waiver (http://creativecommons.org/publicdomain/zero/1.0/) applies to the data made available in this article, unless otherwise stated. 